\title{
DIVORCE AS RISK FACTOR FOR CHILDREN'S PERCEPTION OF PARENTAL REJECTION
}

\begin{abstract}
The aim of this study was to investigate whether divorce is a risk factor for children's perception of parental rejection. The sample included 96 participants in total, of which 33 children whose parents are divorced and 62 whose parents are married. Children in both groups did not differ significantly regarding age or gender (age range: 6-17 years, $M_{\text {div }}=11 \pm 2.9$ years, $M_{\text {marr }}=12 \pm 2.2$ years, approximately $65 \%$ were female in both groups). The Child PARQ short form was used to assess perceptions of parental acceptance/rejection. Higher test scores indicate greater rejection by parents. The findings show that children's age was significantly correlated with the perception of maternal rejection only in the group of divorced parents $(r=.44, p<.05)$. A two-way ANOVA was conducted that examined the effect of gender and family type on PARQ scores. It was found that only the main effect of family type was significant, regardless of the child's sex $(F(1,95)=204.537, p<.001)$. Children of divorced parents assessed both parents as rejecting $\left(M_{m}=79.4 \pm 16.5 ; M_{f}=77.1 \pm 14.8\right)$, while children of married parents assessed them as accepting $\left(M_{m}=36.8 \pm 11.9 ; M_{f}=38.4 \pm 12.5\right)$. Further on, $P A R Q$ scores for mother and father respectively were positively correlated in the group of married parents $(r=.56, p<.01)$, while no significant association was found in the group of divorced parents. Partial $\eta^{2}=.69$ indicates a large effect and confirms that divorce is a significant risk factor of children's perception of parental rejection.
\end{abstract}

Keywords: perceived parental rejection, child, married parents, divorced parents

\section{Introduction}

Divorce is the result of tension and conflict between two people, in which each failed to satisfy the other, to an appropriate degree. Divorce changes the way of life, a new relationship appears, not only in the mutual relation of partners and parents and the child but also in the relations with the wider community to which they belonged. There is no divorce that is not painful for every person, but the more mature ones will sooner find balance and will not seek the support of the children who are least capable of providing it.

Adults and children experience divorce in different ways. For a certain period of time, the child experiences the parent couple, despite the acceptance of their individual different characteristics and roles, as a whole and something that provides basic security. This whole simply collapses with the separation 
after the divorce, not only in the experience of the child but also in the conscious and the unconscious of the parents. Various factors influence how the "grieving process" will unfold for each individual family member. It can be assumed that such "difficult children" (socially and emotionally immature, children who do not respond to stimuli) will experience parental separation much more difficult than children with a better capacity for adaptation (Vidanović et al., 2006).

In cases when parents not having serious and visible conflicts with each other did not give their children enough signs of impending separation, those children found it more difficult to use strategies to deal with and overcome the potentially traumatic experience. Amato (Amato, 1998) states that more than half of divorced families belong to those families, and those children can experience separation with greater difficulty. Some research (Vidanović and Angelković, 2009) suggests that adolescents aged 14-16 years from both elementary and single-parent families do not differ in the degree and propensity for aggression and stimulus seeking. But there are studies (Sigera, 1983) indicating that children whose parents have strong support from biological parents who are still able to continue to function in the parental role, experience the least psychological difficulties.

It is not uncommon for a child in the so-called elementary family to feel unwanted, redundant, and rejected. That is, there are periods in which he/ she feels superfluous, re-examining his/her origin and acceptance in the family in general. But it is a completely normal phase in which doubts, suffering, and loneliness pass spontaneously and developmentally and bring peace and knowledge of acceptance and belonging to the family. But in the case of children whose parents are divorcing or are already divorced, even when they are truly loved by both parents, children go through a difficult and painful period. Children loved by both parents, i.e. who are emotionally attached to both parents, experience their separation as a severe blow precisely because of this, not realizing that the parents are unable to find a common language and remain married for his/her sake. Feeling hurt, deprived, unjustly punished, these children unconsciously try to punish their parents. They do this by increasing the demands, seeking confirmation of their love in the form of attention, talking, gifts, sacrifices, and thus checking which of the parents loves them more, or loves them at all. On the other hand, parents who do not divorce and have insurmountable difficulties in their relationships and difficult conflicts and deep misunderstandings, often and unconsciously use their child's affection to prove something or take revenge on the other spouse.

Usually, parents want to prove to the child that "the other side" does not understand. The one who needs to be a victim does not choose the means to prove that to himself/herself, the surroundings, and the child. When one parent puts himself/herself in the position of a great martyr, he/she tries to find countless proof to back that. Together with the status of a great martyr comes the great sacrifice that the parent is making for the child. In many ways, the child is daily made aware of everything that is being done for him/her, so that on the 
one hand he/she is burdened by feelings of guilt for the sacrifice of the parent, and ambivalent feelings, on the other hand, towards the other parent who is "selfish", "insensitive", but who still loves him/her. Under the weight of these two pressures, the child feels extremely insecure, guilty, and ultimately like a surplus complicating the whole thing (Kondić, 2007). Disharmonious relations and attitudes towards the child by his divorced parents are rather rule than an exception. This war, if lasting for a long time, can practically destroy the child mentally. The selfish and possessive love of the insecure and lonely mother can turn a healthy child into an extremely overprotected, insecure, emotionally immature child, who knows nothing and must not know anything alone. By tying all her love and need of having to her child, the mother prevents him/her from normal development by suffocating the child with her love and giving, in her own way and according to her needs, and not in a way that the child, according to his/her development, really needs. And these are situations in which the child feels unbearable and cornered in, frustrated, strongly needing to get out, to move away, to escape from the suffocation of an unhealthy possessive atmosphere.

On the other hand, the parent who is better off financially, but also needs to "win over" the child, in turn, uses a lot of money to "buy" the child emotionally. The child will accept everything that money brings as a replacement, compensation, and confirmation of love and often in his/her expectations and demands will be insatiably asking for more and bigger confirmation of love of which he/she is not really sure (Vidanović \& Kondić, 2011).

The most difficult cases, i.e. those that lead to serious consequences emotionally and socially are the cases of children from divorced parents who were never actually accepted. If the child for the parent, for one reason or another, was a burden from the start, he/she will become an even greater burden in the case of a divorce. The child passes from one parent to the other, often changing the surroundings and quite logically coming to the conclusion that he/she is redundant and that neither the mother nor the father loves him/her. It significantly affects the formation of the personality, i.e. the character of the child. He/she will have little opportunity to establish real emotional connections in life. The child, furthermore, has no opportunities to form real, realistic, and specifically adapted criteria of interpersonal values, so he/she cannot, not having learned, to behave in relation to them. His/her behaviour is unadjusted, aggressive, and generally inadequate causing condemnation from the environment. This, further on, encourages his/her experience that he/she is unneeded, unwanted, lonely.

Many parents are often unaware of the effects of their own words and actions, much less the reasons for their own behaviour. One reason may be some trait of the child, an unwanted characteristic, or some of his/her actions that may cause the parent to behave in a way that the child perceives as rejection. Parents' moods and their emotional maturity affect the child's sense of acceptance or rejection. When parents feel happy, when they are satisfied with themselves, 
they tolerate the mistakes in their children's behaviour, but when parents have a hard day at work when they are tired, sick, or unhappy, the acceptance of children is usually low. Parents who themselves have been rejected as children tend to reject their children in turn; on the other hand, those who have been accepted and loved have reached greater emotional maturity. They love themselves and achieve greater inner security, and are naturally prone to treat others with love. Attitudes of parental acceptance or rejection, in research, depend on where the children are and who is observing them. For example, some parents are less receptive to their children when they are paying a visit somewhere, or are in a restaurant, or in other public places. Some children are rejected and not loved enough because they came at the wrong time, because of a broken career, interrupted dating of partners, or because there have already been many children in the family, the partner did not want children, etc.

In a longitudinal study of a group of children born to mothers who were suggested not to terminate their pregnancies, twenty years after birth the observational findings were that unwanted children did not have a secure childhood life, sought psychiatric care more often, participated more often in antisocial and criminal behaviour. The control group was of the same sex, age, and place of birth (Kapor-Stanulović, 2007).

Leaving the care of children to grandparents can also in children develop the feeling that the parents have more important things to do than occupy themselves with them and therefore the feeling of rejection may reappear. According to Todorović ((Todorović, 2005) the rejection of the child can be: on the part of both parents; the child has such a feeling even though only one parent avoids the child; the child is loved and accepted by his mother and rejected by the father, but the mother is not able to compensate for the unfavourable attitude of the father, because it has been lasting a very long time and is very pronounced.

If the rejection is not so pronounced and exists only in one parent, the child receives, more or less, a certain amount of desirable emotional experiences. In such families, the child may express a strong need for acceptance by members of various groups. However, this is not enough to form a strong attachment. The need for dependence is unsettled, and the child has trouble establishing close and warm relationships with others. Although he/she needs to be accepted, he/she feels afraid of new situations and people, because the sense of self-worth is low.

Thus, the child responds to parental rejection behaviour with dependent behaviour (Rohner, 1984). Over time, that behaviour can be lost or transformed. A seriously rejected child has never learned how to give love because there were no parents who gave love and who would be a model with their own behaviour. Although the child longed and begged for love, he/she never got it. To protect himself/herself from further emotional trauma, the rejected child tends to close up emotionally. Eventually, the child may stop seeking tenderness from those who are important to him/her. Thus, dependent behaviour, which was a response to parental rejection, disappears. 
Although adults who have been rejected as children have a very strong need for love, often their ability to reciprocate with love is impaired because many of them have become more or less emotionally lonely and unable to respond to potentially close interpersonal relationships.

\section{Research problem and hypotheses}

According to the above elaborated theoretical part in this research, we will present the following research problem: Is divorce a risk factor of the child's perception of parental rejection? Hence, the following hypotheses are formulated:

1. Children perceive divorced parents as more rejecting than children of married parents do;

2. As children age, the child's and adolescent's perception of rejection decreases;

3. The type of family (divorced or married parents) is a factor in the child's perception of rejection;

4. The child's sex is a factor in his/her perception of parental rejection.

\section{Method}

\section{Respondents}

The sample consisted of 33 children whose parents are divorced (only 4 live with the father), of which 14 are male and 19 female, and 63 whose parents are married, of which 28 are male and 35 are female. A total of 96 children and adolescents were surveyed, of which 42 were male and 54 were female. The children were divided into three groups according to their age: 6-11 years old, 12-14 years old, and 15-17 years old.

\section{Instruments}

The Parental Acceptance/Rejection Questionnaire (PARQ) by Ronald Rohner (1984) was used to measure the perception of parental rejection. The questionnaire is a self-assessing questionnaire designed to measure a child's or adolescent's current perception of the extent to which they have experienced parental (maternal and paternal) acceptance or rejection. The questionnaire contains four scales: 1. warmth and emotionality (or cold behaviour and lack of emotions); 2. hostility and aggression; 3 . indifference and neglect; and 4. undifferentiated rejection. Undifferentiated rejection refers to the individual's feelings that the parent does not really love, appreciate, or care for him or her, without having any objective indications that the parent is cold, aggressive, or negligent. In fact, the four scales give a total result of the perceived or remembered parental acceptance or rejection in childhood. Respondents answer to a four-point Likert scale: from (4) "almost always true" to (1) "almost never true". The short form 
of the questionnaire was used, containing 24 statements, of which 8 are for the scale of emotionality and warmth, 6 for hostility and aggression, 6 for indifference and neglect, and 4 for undifferentiated rejection. It should be noted that the total score is obtained when the answers on the heat scale are reversed and added up to the scores from the other three scales. Thus, the total score indicates the perception of parental rejection, i.e. a higher score signifies a higher perceived parental rejection. The minimum score on the entire scale is 24 , while the maximum is 96. The reliability of the scale tested on the Macedonian population is Cronbach's Alpha $=0.90$.

\section{Results}

Table 1 presents the basic descriptive indicators of the variable parents' rejection for the mother and the father separately, for all respondents. Arithmetic means show that rejection by both parents is perceived as relatively low in all respondents. The result of the arithmetic mean of parental rejection perception in children living with both parents and children of divorced parents is interesting. Namely, the children of married parents perceive the parents as low on the rejection scale, while the children of divorced parents perceive the parents higher on the rejection scale.

\section{Table 1.}

Arithmetic means and standard deviations of the variable parental rejection perception for all respondents and for children of married and of divorced parents

\begin{tabular}{lcclcc}
\hline & N & $\begin{array}{l}\text { min. } \\
\text { score }\end{array}$ & max score & M & SD \\
\hline $\begin{array}{l}\text { Maternal rejection } \\
\text { Paternal rejection }\end{array}$ & 96 & 24.00 & 96.00 & 51.43 & 24.50 \\
$\begin{array}{l}\text { Maternal rejection } \\
\text { (married) }\end{array}$ & 63 & 24.00 & 96.00 & 51.70 & 22.77 \\
$\begin{array}{l}\text { Paternal rejection } \\
\text { (married) }\end{array}$ & 63 & 24.00 & 78.00 & 38.38 & 11.90 \\
$\begin{array}{l}\text { Maternal rejection } \\
\text { (divorced) }\end{array}$ & 33 & 37.00 & 96.00 & 79.42 & 16.52 \\
$\begin{array}{l}\text { Paternal rejection } \\
\text { (divorced) }\end{array}$ & 33 & 34.00 & 96.00 & 77.12 & 14.82 \\
\hline
\end{tabular}

Table 2 shows the differences in the arithmetic means using the statistical t-test. The results indicate that the difference in the perception of rejection from both mother and father in children of married parents and of divorced parents is statistically significant. Children of divorced parents perceive greater rejection from their parents than children of married parents. 
Table 2.

Difference in arithmetic means of parental rejection perception in children of married parents and of divorced parents

\begin{tabular}{llll}
\hline & $\mathbf{N}$ & $\mathbf{t}$ & Sig. \\
\hline Maternal rejection & 63 & -14.55 & 0.00 \\
Paternal rejection & 33 & -13.50 & 0.00 \\
\hline
\end{tabular}

According to the age of the children, the results show that in children of married parents, the child's age is an important factor in the perception of rejection by the parents (Table 3). As age increases, children of married parents see an increase in the perception of rejection by the father. In children of divorced parents, the perception of rejection by the mother increases with age.

Table 3.

Correlation of the variables of child's age with the type of family and perception of rejection by mother and father

\begin{tabular}{|c|c|c|c|c|c|}
\hline $\begin{array}{l}\text { Type of } \\
\text { family }\end{array}$ & $\mathbf{N}$ & & Child's age & $\begin{array}{l}\text { Maternal } \\
\text { rejection }\end{array}$ & $\begin{array}{l}\text { Paternal } \\
\text { rejection }\end{array}$ \\
\hline \multirow{3}{*}{$\begin{array}{l}\text { Children } \\
\text { of married } \\
\text { parents }\end{array}$} & & $\begin{array}{l}\text { Child's } \\
\text { age }\end{array}$ & 1 & -0.227 & -0.135 \\
\hline & & $\begin{array}{l}\text { Maternal } \\
\text { rejection }\end{array}$ & & 1 & $0.565^{* *}$ \\
\hline & 63 & $\begin{array}{l}\text { Paternal } \\
\text { rejection }\end{array}$ & & & 1 \\
\hline \multirow{3}{*}{$\begin{array}{l}\text { Children } \\
\text { of divorced } \\
\text { parents }\end{array}$} & & $\begin{array}{l}\text { Child's } \\
\text { age }\end{array}$ & 1 & $0.435^{* *}$ & -0.079 \\
\hline & & $\begin{array}{l}\text { Maternal } \\
\text { rejection }\end{array}$ & & 1 & -0.176 \\
\hline & 33 & $\begin{array}{l}\text { Paternal } \\
\text { rejection }\end{array}$ & & & 1 \\
\hline
\end{tabular}

Table 4 leads to the conclusion that the sex of the child is not a factor for a greater perception of rejection by the mother, while the type of family (married and divorced) has a greater effect on the variable perception of rejection by the mother. 
Table 4.

Testing the effects of the variables sex of the child and type of type on the variable rejection by the mother

\begin{tabular}{|c|c|c|c|}
\hline & & $\mathbf{F}$ & Sig. \\
\hline Sex & & 0.103 & 0.750 \\
\hline Type of family & 94 & 204.537 & 0.000 \\
\hline $\begin{array}{l}\text { Sex and type of } \\
\text { family }\end{array}$ & 94 & 0.069 & 0.793 \\
\hline
\end{tabular}

Similar results were obtained when measuring the effects of the variable rejection by the father (Table 5). Namely, the sex of the child separately and together with the type of family is not a factor for the perception of rejection of the child, but only the type of family is an important factor for the perception of rejection by the father.

Table 5.

Testing the effects of the variables sex of the child and type of type on the variable rejection by the father

\begin{tabular}{llll}
\hline & df & F & Sig. \\
\hline Sex & & 0.000 & 0.984 \\
Type of family & 94 & 174.743 & 0.000 \\
$\begin{array}{l}\text { Sex and type of } \\
\text { family }\end{array}$ & 94 & 0.009 & 0.926 \\
$\mathbf{R}^{2}=0.660$ & &
\end{tabular}

\section{Discussion}

Every child reacts to his/her parents divorcing, and although children are considered flexible and open to life changes, their dependence on parents makes them more vulnerable to the turbulence of family life. Although divorce is highly stressful, it also brings some benefits to parents, such as relieving tension, freedom, and a chance to find a more appropriate partner. Children, on the other hand, almost always see their parents' divorce as a loss and often look for guilt in themselves. Many factors affect how parents will feel after a divorce. Children are afraid of losing parental support, care and love because their parents are obsessed with their problems and are often not sensitive enough to the child's needs.

However, these reactions vary depending on the age, sex, personality, and temperament of the child. This study examined whether the divorce of parents was a risk factor for a child's perception of parental rejection. Further on, 
whether the perception of rejection by the parents is related to the age of the child, the type of family, and the sex of the child. The PART theory was used as a theoretical framework in the research. The results obtained confirmed the hypotheses. Namely, the research findings confirmed that children perceive divorced parents as more rejecting than do children of married parents. Similar results were obtained in studies by Demo \& Acock (1996) and Hertherington (1993), where changes in family structure, socioeconomic difficulties, and parental stress affect a child's adjustment to the new situation and are most often reflected in dysfunctional family relationships. If there is no dysfunction in family relationships, these risk factors will be less likely to compromise the child's adjustment. In other words, the child will feel less unwanted or rejected, i.e. will retain the positive experience of the parents, such as the acceptance, warmth, and care of the parents.

Regarding the age of the child, it was assumed that younger children perceive rejection from both divorced parents more than older children and adolescents. Francke's research (Francke, 1983, according to Aylon \& Flasher, 1993) indicated that during the interviews of children of divorced parents, it was observed that they experienced rejection from their parents even though that happened much earlier. Other research shows that young children are at greater risk of developing social and emotional development problems than older children (Allison \& Furstenberg, 1989). The authors state that young children are not able to realistically assess the situation and are more anxious out of fear of complete abandonment by both parents and more often blame themselves for the parents' divorce. Researchers who have dealt with adolescents' adaptation to divorce or remarriage of parents have found that adjustment problems may arise and intensify. Adolescent adjustment may be more difficult during this period than in young children, but on the other hand, the impressive capacity for increasing maturity and independence in response to a family crisis and the need to help parents may be strengthened (Weiss, 1975).

Regarding the sex of the child, some studies have shown that males respond to divorce with behavioural problems and females with depression (Emery, 1982). However, adolescents of both sexes from divorced and combined families show more behavioural problems and depression than adolescents from elementary families (Amato \& Keith, 1991; Hetherington, 1993). This research also found that the sex of the child does not play a role in the perception of parental behaviour of divorced parents, as well as in the perception of parents in elementary families.

Finally, the notion that the effects of divorce on children are uniform, that is, that all children act the same is an unsustainable simplification. Numerous studies have shown that the consequences of divorce vary and depend on many factors, such as: personality factors (sex, age, person's cognitive and emotional capacity, resilience), family factors (pre- and post-divorce parental conflicts, the capacity of parents for post-divorce parenting, family functionality) 
and environmental factors (relationships with peers, extended family, school, extracurricular activities, etc.).

\section{Literature}

Allison, C. R., Furstenberg, F.F. (1989). How marital dissolution affects the children: Variations by age and sex, Developmental Psychology, 25, 540549.

Amato, P. (1998). More than many? Men 's contributions to their children's lives. In: A. Booth, A. Crouter, (Eds.), Men in families: When do they get involved? What difference does it make? Mahwah: Lawrence Erlbaum Associates Inc.

Amato, P. R., Keith, B. (1991). Parental divorce and well-being of children, A meta analyses, Psychological Bulletin. 110, 26-46.

Aylon, O., Flasher, A. (1993). Chain reaction, Children and Divorce, Jessica and Kingsley Publishers, London and Bristol, Pennsylvania.

Demo, H.D., Acock, C.A. (1996). Family structure, family process, and adolescent well-being, Journal of Research on Adolescence, 6, 457-488.

Emery, R.E. (1982). Interpersonal conflict and the children of discord and divorce, Psychological Bulletin, 92, 310-330.

Hertherington, E.M. (1993). An overview of the Virginia Longitudinal Study of Divorce and Remarriage with a focus on early adolescence, Journal of Family Psychology, 7, 39-56.

Kapor-Stanulović, N. (2007). Psihologija roditeljstva. Beograd, Nolit.

Kondić, K. (2007). Psihologija ja. Beograd. Nolit.

Rohner, R. (1984). Handbook for the Study of parental Acceptance and rejection. The University of Conecticut.

Todorović, J. (2005). Vaspitni stilovi roditelja i samopoštovanje adolescenata. Niš, Filozofski fakultet vo Niš.

Weiss, R. (1975). Marital Separation: Copping with the end of marriage and the Transition to Being Single again, New York, Basic Books.

Видановиќ, С., Ангелковиќ, В. (2009). Агресивност, склоност ка ризичном понашању и структура породице адолесцената. Настава и васпиmarte, 3, 386-398.

Видановиќ, С., Тодоровиќ, Ј., Хедрих, В. (2006). Породиц̧а и посао - изазови и могућности. Ниш, Филозофски факултет у Нишу.

Кондиќ, К., Видановиќ, С. (2011). О децุи и родитељима. Фидозофски факултет у Нишу.

Шурбановска, О. (2013). Родителите и однесуваньето на детето во учихиитето. Скопје, Филозофски факултет. 